\title{
Geochemistry of Sandstones from the Aghajari Formation, Folded Zagros Zone, Southwestern Iran: Implication for Paleoweathering condition, Provenance, and Tectonic Setting
}

\author{
Mohammad Sahraeyan $^{1}$ and Mohammad Bahrami ${ }^{2}$ \\ ${ }^{1}$ Department of geology, Khorasgan (Esfahan) Branch, Islamic Azad University, \\ Esfahan, Iran \\ E-mail: M.Sahraeyan@yahoo.com \\ ${ }^{2}$ Department of geology, Fars Science and Research Branch, Islamic Azad \\ University, Shiraz, Iran \\ E-mail: Mbahrami1329@yahoo.com
}

\begin{abstract}
The Late Miocene- Pliocene Aghajari Formation is exposed throughout the Folded Zagros Zone and consists of fluvial sediments. Aghajari Formation sandstones are characterized by low to moderate $\mathrm{SiO}_{2}$ contents, variable abundances of major elements and a relatively high proportion of ferromagnesian elements. Evidence from discrimination diagrams of sedimentary provenance, tectonic setting, major element geochemistry, and $\mathrm{Sc} / \mathrm{Th}, \mathrm{Cr} / \mathrm{Th}, \mathrm{Co} / \mathrm{Th}, \mathrm{Zr} / \mathrm{Sc}, \mathrm{La} / \mathrm{Sc}$, $\mathrm{La} / \mathrm{Co}, \mathrm{Cr} / \mathrm{Sc}$, and $\mathrm{Y} / \mathrm{Ni}$ values show that the Aghajri Formation sediments were derived from felsic and intermediate sources. The chemical index of alteration (CIA: 59.2- 77.14) revealed low to moderately weathered source rocks. The major and trace element concentrations indicate deposition in an active continental margin and passive continental margin settings.
\end{abstract}

Keywords: Aghajari Formation, Folded Zagros Zone, Sandstone, Geochemistry, Iran. 


\section{Introduction}

Geochemical signatures of basin clastic sedimentary rocks provide important sources of information [1]. In particular the use of immobile major and trace elements that are thought to be carried in the particulate load have been found to be useful indicators of source terrain, weathering, tectonic, and environmental evolution [2, 3, 4]. Trace elements such as rare earth elements (REEs) are relatively insoluble and as a result, their original compositions are not upset during the sedimentary processes. On a global scale, mudstone/shale chemistry reflects the average composition of the continental crust [5]. Because of the fine grained nature and impermeability, mudrocks retain most of the mineral constituents of the source rocks.

The immobile oxides and elements, such as $\mathrm{Al}_{2} \mathrm{O}_{3}, \mathrm{Fe}_{2} \mathrm{O}_{3}, \mathrm{TiO}_{2}, \mathrm{Th}, \mathrm{Sc}, \mathrm{Co}, \mathrm{Zr}$, and REEs, are particularly useful for provenance interpretations. Being immobile phases in aqueous systems, these elements retain the original source concentration within the shale $[2,6,7,8,9,10,11]$. The whole rock geochemistry is a useful tool for analyzing a tectonically complex region $[1,6]$.

\section{Geology Setting}

The geological evidence suggests that the Zagros region was part of a passive continental margin, which subsequently underwent rifting during the PermoTriassic and collision during the Late Tertiary [12, 13, 14]. In fact, the Zagros fold- thrust belt lies on the northeastern margin of the Arabian plate and has been divided into NW- SE trending structural zones (imbricated and simply folded belt) parallel to the plate margin separated by major fault zones such as the High Zagros and mountain front faults. In addition to the tectonic divisions parallel to the mountain belt, the belt has also been divided laterally to the Lurestan, Dezful embayment and Fars regions from northwest to southeast [15].

The Aghajari Formation is present throughout the Zagros Basin, but, because of its gradual subsidence during deposition, it is best developed in Dezful Embayment (about 3000 meters) and probably increases in the synclines of this region. The Aghajari Formation was studied in detail and formally defined by James and Wynd [16]. Aghajari Formation in its type section, consists of 2966 meters alternation layers of brown to gray calcareous sandstones and red marls with gypsum interlayers, and red siltstones [17]. Aghajari Formation in Zagros Zone is characterized with two lithofacies groups that each develops in internal Fars and northwestern of Dezful Embayment. The first is mostly continental clastic sediments (i.e. mudstone, sandstone, and conglomerate), but the second one, that spreads in coastal Fars, has a marine characteristics (i.e. marl with gypsum inter-layers). Deposition of the Aghajari Formation took place during the Late Miocene- Pliocene [18], but it doesn't have unity in age and becomes younger from northwestern to south-eastern and from northeastern to 
southwestern. In the type section, the lower contact with Mishan Formation is dominantly gradual and sometimes abrupt. The upper contact with Bakhtyari Formation is sometimes gradual and conformable and occasionally abrupt and unconformable. In the study area, the lower contact with Razak Formation and the upper contact with Bakhtyari Formation are gradual [15].

Aghajri Formation is equivalent to Fat'ha and Injana Formations in Iraq, Upper Fars and Lower Fars in Syria and Kuwait, and Kial and Jabal Kibrit Formations in Saudi Arabia [19]. The Aghajari Formation includes Lahbari Clastic Member at its upper part. The above mentioned studies focused primarily on oil producing areas (southwestern of Iran). Sedimentology, sedimentary environment, and morphotectonical evolution of Aghajari and Bakhtyari Formations are tought out by Bahrami [20]. A detailed account of the lithology, sedimentary facies, and sedimentary environments of Aghajari Formation is reported by Bahrami [21] and Sahraeyan et al. [22] as fluvial deposits. According to Sahraeyan and Bahrami $[15]$, these sandstones were distinguished as lithic arenite and sublitharenite.

No detailed studies on the geochemistry of this formation have been carried out. The purpose of the present study is to use a geochemical approach to decipher the paleoweathering condition, provenance, and tectonic setting of the Aghajari Formation sandstones from the Folded Zagros Zone. This is the first study that presents these data of Aghajari Formation sediments.

\section{Materials and Methods}

Sandstone samples from the silisiclastic deposits of the Aghajari Formation (Late Miocene- Pliocene) were studied in the present work. Some 75 sandstone samples were collected.

Fifteen of the samples were analyzed by ICP-MS analysis for the major and trace element geochemistry, and gravimetric method for $\mathrm{SiO} 2$ and volatile components. The ICP-MS analysis was carried out at the Geological Survey of Iran laboratory, Iran.

Where $\mathrm{CaO}^{*}$ is the amount of $\mathrm{CaO}$ incorporated in the silicate fraction of the rock and the values are in molar proportions to emphasize mineralogical relationship [23]. The highly variable values of $\mathrm{CaO}$ in the Aghajari Formation sandstones, ranging Between 16.66 to $37.18 \mathrm{wt} \%$ in sandstone, are because of the secondary $\mathrm{CaCO}_{3}$.

Sandstone geochemical data was plotted following the classification schemes of Herron [24] and Pettijohn et al. [25]. Composition of the major element oxides of the sandstone was used for provenance determination applying tectonic discriminatory plots of Bhatia [6] and Roser and Korsch [26]. Alike, ratios of the $\mathrm{La} / \mathrm{Sc}$ versus $\mathrm{Ti} / \mathrm{Zr}$ and $\mathrm{La} / \mathrm{Y}$ versus $\mathrm{Sc} / \mathrm{Cr}$ of the sandstone on binary plots were used for distinguish the tectonic setting. 


\section{Sandstone Classification}

Major and trace elements analyses of 15 Aghajari Formation sandstones are listed in Table 1. From Table 1, it is apparent that most of the samples are moderate to high in $\mathrm{SiO}_{2}$ (28.68-59.68\%), have moderate $\mathrm{Al}_{2} \mathrm{O}_{3}(2.07-7.43 \%)$, and a limit range of $\mathrm{K}_{2} \mathrm{O}(0.37-1.64 \%$; averaging $1 \%)$. In contrast, they possess low average contents of $\mathrm{TiO}_{2}, \mathrm{MnO}, \mathrm{CaO}$, and $\mathrm{Na}_{2} \mathrm{O} . \mathrm{Fe}_{2} \mathrm{O}_{3}$ and $\mathrm{MgO}$ are also low and collectively sum to less than $5 \%$.

Bulk chemical variations of the major elements in the mudstone of the Neogene molasse sequence are plotted on variation diagrams using $\mathrm{Al}_{2} \mathrm{O}_{3}$ along $\mathrm{x}$-axis and compared with Upper Continental Crust (UCC) and Post-Archaen Australian Shale (PAAS) from Taylor and McLennan [2]. The $\mathrm{TiO}_{2}, \mathrm{Al}_{2} \mathrm{O}_{3}, \mathrm{Fe}_{2} \mathrm{O}_{3}, \mathrm{~K}_{2} \mathrm{O}$, and $\mathrm{SiO}_{2}$ in the sandstone samples of the Aghajari Formation are depleted relative to PAAS and UCC (Figs. 1A, B, C, and D). MnO content is a wide range from lower than UCC to higher than PAAS (Fig. 1E). MgO content of the studied samples is mostly lower than PAAS and UCC, excluding two samples whose $\mathrm{MgO}$ is similar to PAAS and UCC, also two samples is higher than PAAS and UCC (Fig. 1F). $\mathrm{P}_{2} \mathrm{O}_{5}$ and $\mathrm{Na}_{2} \mathrm{O}$ is dominantly less than UCC and PAAS, excluding a few samples having content similar to PAAS (Figs. $1 \mathrm{G}$ and $\mathrm{H}$ ).
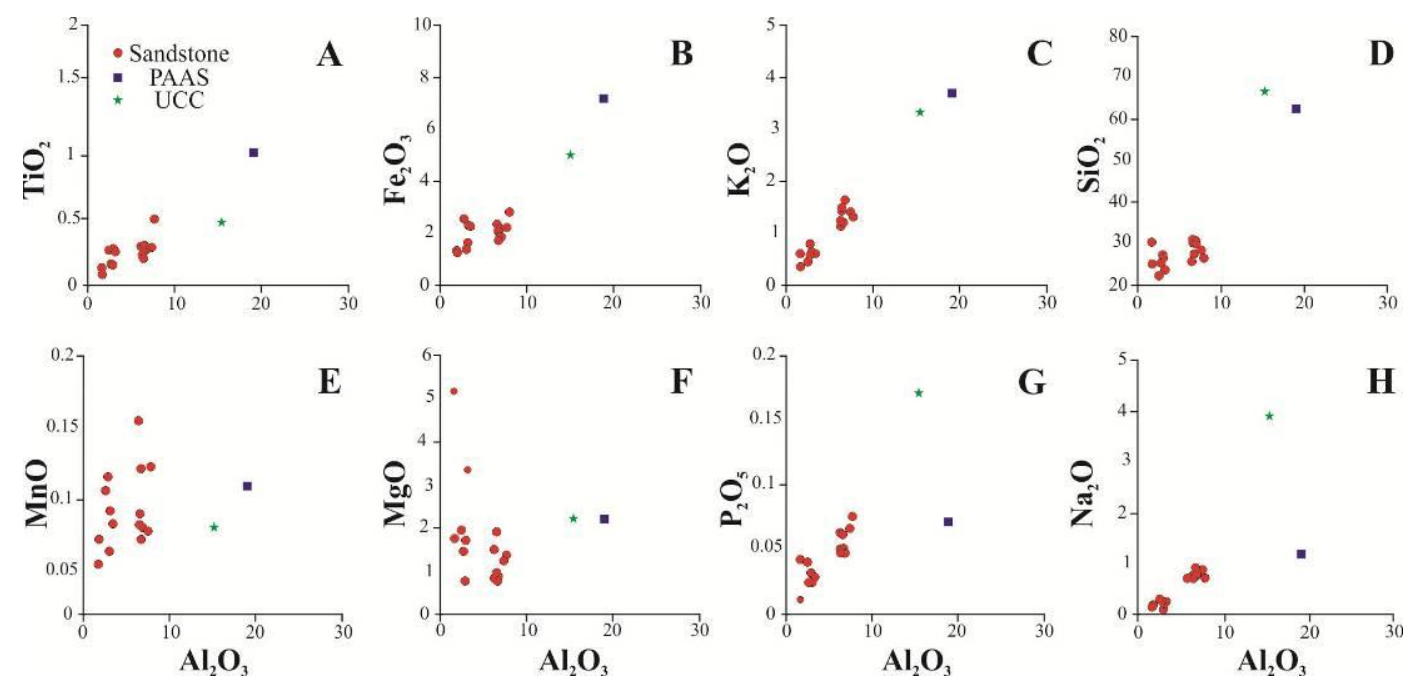

Fig. 2- Various oxides of the sandstone samples of Aghajari Fotmation plotted against $\mathrm{Al}_{2} \mathrm{O}_{3}$. X-axis and $\mathrm{Y}$-axis are weight percent composition. Average data of

UCC and PAAS ${ }^{[2]}$ are also plotted for comparison in the binary diagrams.

The less depleted $\mathrm{Na}_{2} \mathrm{O}$ contents in the sandstones of the Aghajari Formation compared to the PAAS could be related to the presence of albite and clay minerals. $\mathrm{MgO}$ is usually associated with calcite, dolomite, and ferroan carbonates. High $\mathrm{MgO}$ levels reflect the presence of carbonate minerals, whereas low concentration 
is linked to clay minerals. The depletion of $\mathrm{Na}_{2} \mathrm{O}$ compared to PAAS reflect moderate to strong weathering, recycling of the source rock, and their removal during transportation $[8,27,28]$.

The high $\mathrm{K}_{2} \mathrm{O} / \mathrm{Na}_{2} \mathrm{O}$ ratios are attributed to the common presence of K-bearing minerals such as $\mathrm{K}$-feldspar and mica, illite, muscovite, and biotite [29, 30, 31, 32]. A positive correlation between $\mathrm{K}_{2} \mathrm{O}$ and $\mathrm{Al}_{2} \mathrm{O}_{3}$ implies that the concentrations of the K-bearing minerals have significant influence on $\mathrm{Al}$ distribution and suggests that the abundance of these elements is primarily controlled by the content of clay minerals ${ }^{[29]}$. However, a contribution from the feldspars is indicated from their $\mathrm{Al}_{2} \mathrm{O}_{3} / \mathrm{SiO}_{2}$ ratios. Based on these ratios, the Aghajari Formation sandstones can be classified chemically as lithic arenite, sublitharenite, and Fe-sands [24] (Fig. 2A) and as lithic arenite, subarkose, and sublitharenite [25] (Fig. 2B).

Table 1- Major and trace elements of the selected sandstone samples of the

Aghajari Frormation sandstones, Folded Zagros Zone, Iran, along with their modified chemical index of alteration (CIA; ${ }^{[23]}$ ).

\begin{tabular}{ccccccccc}
\hline Sample & $\mathrm{SiO}_{2}$ & $\mathrm{TiO}_{2}$ & $\mathrm{Al}_{2} \mathrm{O}_{3}$ & $\mathrm{Fe}_{2} \mathrm{O}_{3}$ & $\mathrm{MnO}$ & $\mathrm{MgO}$ & $\mathrm{CaO}$ & $\mathrm{Na}_{2} \mathrm{O}$ \\
\hline $\mathrm{AJ}-5$ & 59.68 & 0.25 & 6.28 & 2.19 & 0.069 & 0.85 & 18.74 & 0.79 \\
$\mathrm{AJ}-12$ & 58.17 & 0.16 & 2.07 & 1.46 & 0.039 & 5.19 & 34.98 & 0.17 \\
$\mathrm{AJ}-18$ & 57.82 & 0.28 & 6.6 & 1.98 & 0.067 & 0.88 & 18.18 & 0.82 \\
$\mathrm{AJ}-26$ & 57.35 & 0.22 & 6.32 & 1.85 & 0.078 & 0.9 & 20.59 & 0.73 \\
$\mathrm{AJ}-34$ & 51.07 & 0.3 & 7.16 & 2.34 & 0.064 & 1.25 & 19.74 & 0.91 \\
$\mathrm{AJ}-40$ & 58.65 & 0.27 & 6.45 & 2 & 0.058 & 0.84 & 16.66 & 0.95 \\
$\mathrm{AJ}-47$ & 41.13 & 0.3 & 6.18 & 2.46 & 0.151 & 1.51 & 28.74 & 0.7 \\
$\mathrm{AJ}-56$ & 47.07 & 0.18 & 3.19 & 1.77 & 0.049 & 0.77 & 31.76 & 0.09 \\
$\mathrm{AJ}-66$ & 44.1 & 0.48 & 7.43 & 2.91 & 0.114 & 1.37 & 25.7 & 0.74 \\
$\mathrm{AJ}-81$ & 28.68 & 0.28 & 2.81 & 2.66 & 0.096 & 1.95 & 37.18 & 0.3 \\
$\mathrm{AJ}-87$ & 44.03 & 0.29 & 3.25 & 2.43 & 0.08 & 1.73 & 30.01 & 0.21 \\
$\mathrm{AJ}-92$ & 38.94 & 0.12 & 2.13 & 1.44 & 0.058 & 1.77 & 35.99 & 0.18 \\
$\mathrm{AJ}-109$ & 47.63 & 0.3 & 6.42 & 2.27 & 0.113 & 1.91 & 26.21 & 0.78 \\
$\mathrm{AJ}-116$ & 39.72 & 0.19 & 3.03 & 1.52 & 0.106 & 1.46 & 32.5 & 0.26 \\
$\mathrm{AJ}-127$ & 33.68 & 0.27 & 3.45 & 2.38 & 0.07 & 3.35 & 31 & 0.25 \\
\hline & & & & & & & & \\
\hline Sample & $\mathrm{K}_{2} \mathrm{O}$ & $\mathrm{P}_{2} \mathrm{O}_{5}$ & $\mathrm{Zr}$ & $\mathrm{Nb}$ & $\mathrm{Th}$ & $\mathrm{Pb}$ & $\mathrm{Ga}$ & $\mathrm{Zn}$ \\
\hline AJ-5 & 1.5 & 0.048 & 39.66 & 8.13 & 2.98 & 4.5 & 8.11 & 13.01 \\
$\mathrm{AJ}-12$ & 0.37 & 0.015 & 16.72 & 4.94 & 0.3 & 8.41 & 5.33 & 0.68 \\
$\mathrm{AJ}-18$ & 1.64 & 0.047 & 38.32 & 8.9 & 3.92 & 0.5 & 6.82 & 10.52 \\
$\mathrm{AJ}-26$ & 1.45 & 0.016 & 42.79 & 7.15 & 3.8 & 14.06 & 7.82 & 10.76 \\
\hline
\end{tabular}




\begin{tabular}{|c|c|c|c|c|c|c|c|c|}
\hline AJ-34 & 1.41 & 0.063 & 44.18 & 9.42 & 6.43 & 4.69 & 6.03 & 15.86 \\
\hline AJ-40 & 1.22 & 0.048 & 34.46 & 8.65 & 1.97 & 4.05 & 5.31 & 8.6 \\
\hline AJ-47 & 1.14 & 0.06 & 49 & 9.84 & 3.28 & 13.52 & 12.96 & 18.4 \\
\hline AJ-56 & 0.6 & 0.027 & 34.47 & 5.77 & 2.96 & 3.41 & 4.47 & 7.19 \\
\hline AJ-66 & 1.32 & 0.07 & 51.77 & 15.66 & 6.85 & 1.01 & 7.55 & 19.65 \\
\hline AJ-81 & 0.46 & 0.04 & 31.48 & 8.44 & 4 & 16.04 & 4.48 & 12.44 \\
\hline AJ-87 & 0.64 & 0.032 & 34.89 & 9.35 & 3.01 & 5.06 & 4.92 & 11.27 \\
\hline AJ-92 & 0.62 & 0.042 & 20.91 & 3.5 & 2.41 & 12.17 & 7.62 & 0.62 \\
\hline AJ-109 & 1.21 & 0.058 & 40.7 & 9.73 & 4.91 & 10.73 & 11.98 & 18.75 \\
\hline AJ-116 & 0.8 & 0.026 & 24.71 & 5.84 & 0.3 & 18.29 & 4.13 & 2.18 \\
\hline AJ-127 & 0.62 & 0.03 & 32.15 & 8.33 & 3.83 & 5.16 & 5.37 & 9.6 \\
\hline Sample & $\mathrm{Sc}$ & $\mathrm{Ta}$ & $\mathrm{Co}$ & $\mathrm{Li}$ & $\mathrm{Be}$ & $\mathrm{B}$ & $\mathrm{U}$ & $\mathrm{W}$ \\
\hline AJ-5 & 5.6 & 0.5 & 11.12 & 0.3 & 0.54 & 12.12 & 2.63 & 1.47 \\
\hline AJ-12 & 5.11 & 1.83 & 0.83 & 0.3 & 0.16 & 10.08 & 2.45 & 1.95 \\
\hline AJ-18 & 5.51 & 0.77 & 8.47 & 0.3 & 0.52 & 10.53 & 3.43 & 1.19 \\
\hline AJ-26 & 5.89 & 0.1 & 9.3 & 0.3 & 0.51 & 6.44 & 2.51 & 1.29 \\
\hline AJ-34 & 6.79 & 0.27 & 15.43 & 2.48 & 0.6 & 16.12 & 3.63 & 1.31 \\
\hline AJ -40 & 6.15 & 0.15 & 11.46 & 0.3 & 0.56 & 16.04 & 2.34 & 1.28 \\
\hline AJ-47 & 7.1 & 0.1 & 17.42 & 1.03 & 0.53 & 12.51 & 3.49 & 1.4 \\
\hline AJ-56 & 5.22 & 0.74 & 11.14 & 0.3 & 0.31 & 10.85 & 2.62 & 1.18 \\
\hline AJ-66 & 8.51 & 0.29 & 16.69 & 1.93 & 0.58 & 9.17 & 4.11 & 1.59 \\
\hline AJ-81 & 6.4 & 0.22 & 23.39 & 0.3 & 0.35 & 19.99 & 4.07 & 1.58 \\
\hline AJ-87 & 6.17 & 0.18 & 17.83 & 0.3 & 0.34 & 7.48 & 3.27 & 1.37 \\
\hline AJ-92 & 3.6 & 0.4 & 8.95 & 0.3 & 0.24 & 11.53 & 2.31 & 1.64 \\
\hline AJ-109 & 7.35 & 0.9 & 15.27 & 1.59 & 0.53 & 5.51 & 3.17 & 1.56 \\
\hline AJ-116 & 4.46 & 0.67 & 10.92 & 0.3 & 0.3 & 8.74 & 2.79 & 1.28 \\
\hline AJ-127 & 6.99 & 0.1 & 24.7 & 0.3 & 0.29 & 9.24 & 3.28 & 1.78 \\
\hline Sample & $\operatorname{Pr}$ & $\mathrm{Nd}$ & $\mathrm{Sm}$ & $\mathrm{Eu}$ & $\mathrm{Gd}$ & $\mathrm{Y}$ & Mo & $\mathrm{Ni}$ \\
\hline AJ-5 & 1.69 & 6.24 & 2.43 & 0.71 & 1.72 & 10.01 & 21.24 & 50.61 \\
\hline AJ-12 & 1.37 & 0.14 & 1.92 & 0.37 & 0.75 & 5.32 & 10.67 & 92.7 \\
\hline AJ-18 & 1.77 & 8.81 & 2.2 & 0.66 & 1.78 & 9.86 & 12.04 & 34.16 \\
\hline AJ-26 & 1.9 & 7.3 & 2.35 & 0.54 & 1.66 & 10.18 & 10.05 & 39.64 \\
\hline AJ-34 & 1.68 & 7.89 & 2.98 & 0.63 & 1.55 & 10.2 & 13.33 & 68.72 \\
\hline AJ-40 & 1.76 & 8.68 & 3.26 & 0.77 & 1.68 & 9.33 & 19.39 & 42.26 \\
\hline AJ-47 & 2.12 & 6.48 & 2.75 & 0.64 & 1.91 & 12.3 & 8.54 & 82.38 \\
\hline AJ-56 & 1.69 & 6.6 & 1.35 & 0.59 & 1.28 & 9.51 & 11.36 & 71.87 \\
\hline
\end{tabular}




\begin{tabular}{|c|c|c|c|c|c|c|c|c|}
\hline AJ-66 & 2.66 & 13.54 & 3.51 & 0.95 & 2.44 & 14.77 & 17.25 & 60.11 \\
\hline AJ-81 & 2.52 & 4.91 & 2.46 & 0.57 & 1.6 & 8.82 & 10.4 & 134 \\
\hline AJ-87 & 2.57 & 2.22 & 3.12 & 0.67 & 1.49 & 9.73 & 11.86 & 106 \\
\hline AJ-92 & 1.79 & 3.88 & 1.94 & 0.38 & 1.14 & 6.79 & 22.49 & 47.11 \\
\hline AJ-109 & 1.71 & 9.94 & 2.36 & 0.82 & 1.65 & 12.64 & 14.95 & 91.12 \\
\hline AJ-116 & 1.85 & 4.04 & 2.55 & 0.54 & 1.19 & 8.15 & 11.3 & 47.37 \\
\hline AJ-127 & 2.71 & 2.6 & 2.5 & 0.47 & 1.39 & 8.4 & 10.62 & 153 \\
\hline Sample & $\mathrm{Ba}$ & $\mathrm{Rb}$ & $\mathrm{Sr}$ & Ho & $\mathrm{Hf}$ & $\mathrm{Cs}$ & $\mathrm{La}$ & $\mathrm{Ce}$ \\
\hline AJ-5 & 297 & 150 & 212 & 0.74 & 6.09 & 3.12 & 16.83 & 25.65 \\
\hline AJ-12 & 45 & 132 & 211 & 0.7 & 1.24 & 3.43 & 6.15 & 0.75 \\
\hline AJ-18 & 220 & 146 & 212 & 0.59 & 7.63 & 2.29 & 15.22 & 18.99 \\
\hline AJ-26 & 189 & 148 & 197 & 0.68 & 7.29 & 2.21 & 15.81 & 17.79 \\
\hline AJ-34 & 245 & 146 & 222 & 0.75 & 3.83 & 3.09 & 15.77 & 19.25 \\
\hline $\mathrm{AJ}-40$ & 267 & 150 & 180 & 0.65 & 2.8 & 2.78 & 16.36 & 17.78 \\
\hline AJ-47 & 519 & 152 & 346 & 0.77 & 4.34 & 3.44 & 17.22 & 19.88 \\
\hline AJ-56 & 68 & 136 & 183 & 0.73 & 1.24 & 2.75 & 10.66 & 6.65 \\
\hline AJ-66 & 192 & 126 & 288 & 0.94 & 4.82 & 3.71 & 23.54 & 31.15 \\
\hline AJ-81 & 104 & 124 & 377 & 0.87 & 5.5 & 4.55 & 11.54 & 6.63 \\
\hline AJ-87 & 112 & 120 & 277 & 0.78 & 3.48 & 3.76 & 12.63 & 13.47 \\
\hline AJ-92 & 398 & 128 & 256 & 0.65 & 3.05 & 2.93 & 9.16 & 2.22 \\
\hline AJ-109 & 218 & 137 & 436 & 0.79 & 1.66 & 3.32 & 18.01 & 21.98 \\
\hline AJ-116 & 185 & 126 & 382 & 0.59 & 3.61 & 2.82 & 11.6 & 11.6 \\
\hline AJ-127 & 537 & 141 & 247 & 0.67 & 0.04 & 3.98 & 10 & 8.82 \\
\hline Sample & Dy & $\mathrm{Er}$ & $\mathrm{Tm}$ & $\mathrm{Yb}$ & $\mathrm{Sn}$ & $\mathrm{V}$ & $\mathrm{Cu}$ & CIA \\
\hline AJ-5 & 1.18 & 0.51 & 1.38 & 0.9 & 0.68 & 60.49 & 58.15 & 59.79 \\
\hline AJ-12 & 0.7 & 0.5 & 0.97 & 0.68 & 0.5 & 60.19 & 22.59 & 68.32 \\
\hline AJ-18 & 0.91 & 0.55 & 1.13 & 0.91 & 0.61 & 57.76 & 25.68 & 59.6 \\
\hline AJ-26 & 1.14 & 0.5 & 1.22 & 0.89 & 0.56 & 49.05 & 17.1 & 61.41 \\
\hline AJ-34 & 0.96 & 0.58 & 0.94 & 0.94 & 0.76 & 61.73 & 19.19 & 61.3 \\
\hline $\mathrm{AJ}-40$ & 0.61 & 0.53 & 1.12 & 0.88 & 0.63 & 52.45 & 20.26 & 59.2 \\
\hline AJ-47 & 1.08 & 0.61 & 1.27 & 1.15 & 0.74 & 64.21 & 19.12 & 63.6 \\
\hline AJ-56 & 1.26 & 0.5 & 1.25 & 0.89 & 0.53 & 48 & 16.33 & 77.14 \\
\hline AJ-66 & 1.32 & 0.96 & 1.6 & 1.38 & 0.95 & 97.05 & 15.18 & 65.79 \\
\hline AJ-81 & 0.39 & 0.53 & 1.36 & 0.95 & 0.89 & 78.58 & 29.48 & 65.43 \\
\hline AJ-87 & 1.3 & 0.59 & 1.46 & 0.94 & 0.74 & 91.01 & 29.02 & 70.14 \\
\hline AJ-92 & 0.72 & 0.5 & 1.13 & 0.65 & 0.45 & 46.94 & 12.06 & 62.77 \\
\hline
\end{tabular}




\begin{tabular}{ccccccccc}
\hline AJ-109 & 1.4 & 0.6 & 1.45 & 1.09 & 0.72 & 60.06 & 17.36 & 62.35 \\
AJ-116 & 0.91 & 0.5 & 1.09 & 0.88 & 0.54 & 57.74 & 13.53 & 63.77 \\
AJ-127 & 0.73 & 0.52 & 1.38 & 0.88 & 0.75 & 79.51 & 14.31 & 69.79 \\
\hline
\end{tabular}
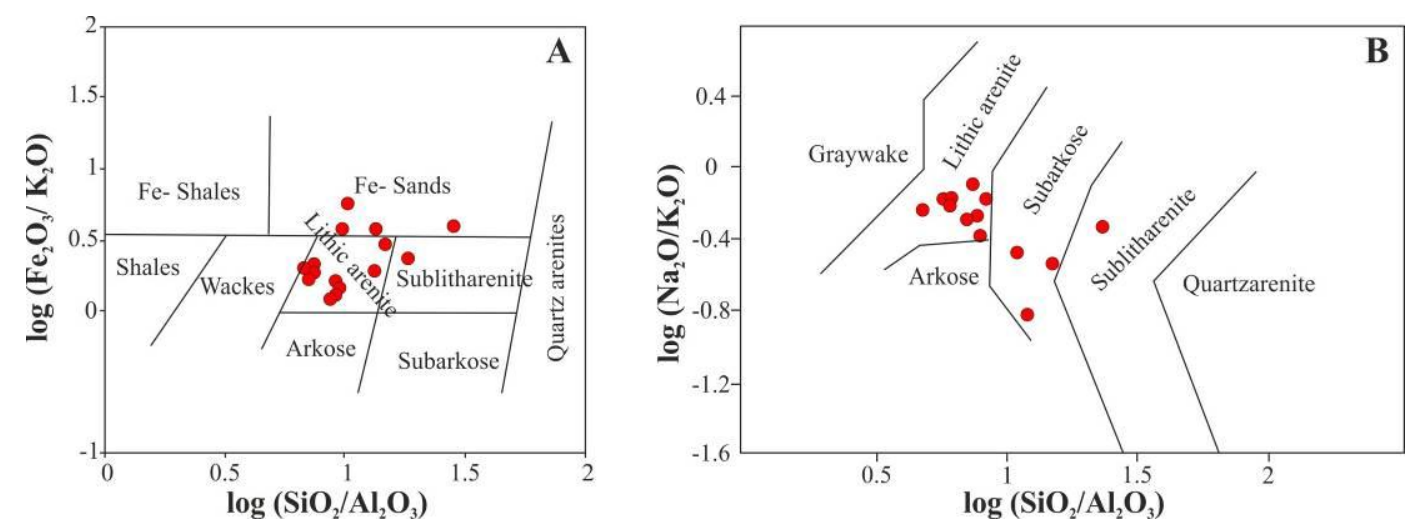

Fig. 2- Chemical classification of samples from the Aghajari Formation sandstones based on binary diagrams. A: $\log \left(\mathrm{SiO}_{2} / \mathrm{Al}_{2} \mathrm{O}_{3}\right)$ versus $\log \left(\mathrm{Fe}_{2} \mathrm{O}_{3} / \mathrm{K}_{2} \mathrm{O}\right)$ diagram of Herron ${ }^{[24]}$; $\mathrm{B}$ : the $\log \left(\mathrm{SiO}_{2} / \mathrm{Al}_{2} \mathrm{O}_{3}\right)$ versus $\log \left(\mathrm{Na}_{2} \mathrm{O} / \mathrm{K}_{2} \mathrm{O}\right)$ diagram of Pettijohn et al. ${ }^{[25]}$.

\section{Provenance}

The concentration of $\mathrm{Zr}$ is used for characterizing the nature and composition of source rocks $[9,11]$. The high $\mathrm{TiO}_{2} / \mathrm{Zr}$ ratios (52.3-96.9) of the sandstones indicate intermediate source rocks $[2,4,8,33,34]$. When plotted on the $\mathrm{TiO}_{2}-\mathrm{Zr}$ diagrams (Fig. 3), these ratios help distinguish among three different source rock types, i.e., felsic, intermediate, and mafic. The $\mathrm{TiO}_{2}$ versus $\mathrm{Zr}$ plot of the sandstones represents predominately intermediate source rocks.

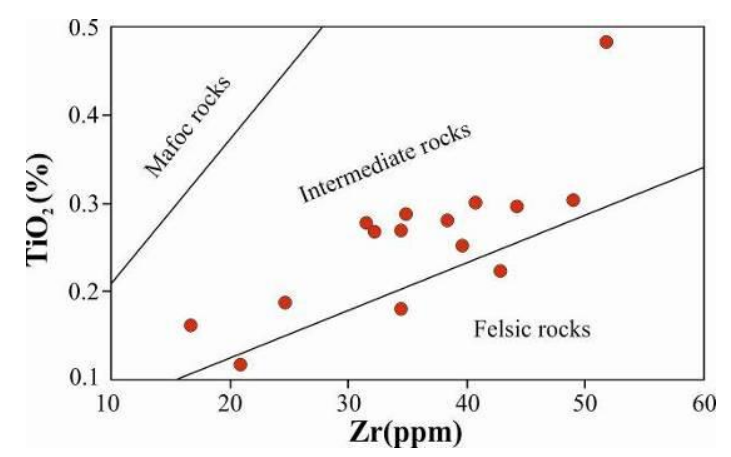

Fig. 3- $\mathrm{TiO}_{2}-\mathrm{Zr}$ plot for the Aghajari Formation sandstones (after [9]). 
Trace elements such as $\mathrm{Cr}, \mathrm{Ni}, \mathrm{Co}$, and $\mathrm{V}$ are useful indicators of mafic and ultramafic sources [28, 33]. Felsic source rocks usually contain lower concentrations of $\mathrm{Cr}, \mathrm{Co}, \mathrm{Ni}$, and $\mathrm{V}$ and higher concentrations of $\mathrm{Ba}, \mathrm{Sr}, \mathrm{Y}$, and $\mathrm{Zr}$ than mafic and intermediate source rocks [2, 28, 34]. The respective average values of the sandstone samples $(\mathrm{Cr}=220, \mathrm{Ni}=74.73, \mathrm{Co}=13.52$, and $\mathrm{V}=64.32)$ are similar/or higher than those in the upper continental crust and PAAS [2].

In the discrimination diagrams for sedimentary provenance after Roser and Korsch [26], all samples of the studied sandstones plot in the quartzose recycled field (Fig. 4).

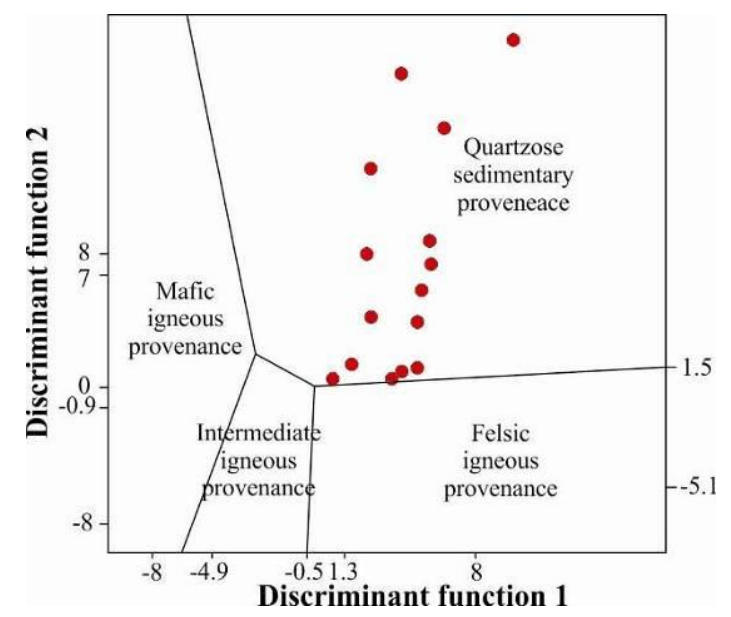

Fig. 4- Provenance discriminant function diagram using major elements for Aghajari Formation sandstones (after ${ }^{[26]}$ ).

The variations in Th and La (indicative of felsic) and, Sc and Co (indicative of mafic) contents have been used to differentiate between felsic and mafic provenance by various authors $[10,35,36,37,38]$. Th/Co versus $\mathrm{La} / \mathrm{Sc}$ bivariate diagram can provide information regarding the source rock characteristics [36, 39]. The Th/Co versus La/Sc plot (Fig. 5) suggests a silisic nature of the source rocks [36]. 


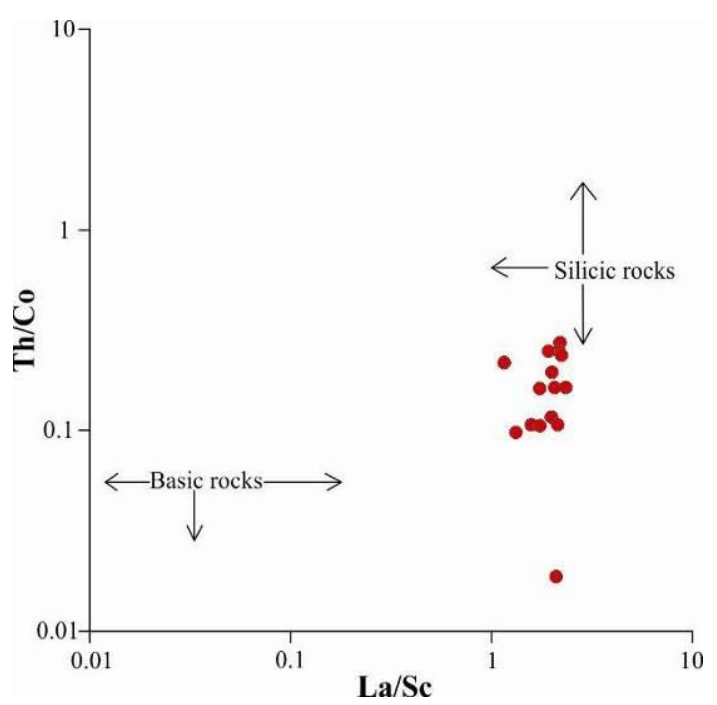

Fig. 5- Th/Co vs. La/Sc plot showing source rock composition for the Aghajari Formation sandstones (after ${ }^{[36]}$ ).

\section{Tectonic Setting}

The major element geochemistry of sandstones can be used for drawing inferences related to the provenance type and the plate tectonic setting of ancient sedimentary basins $[6,26,40]$.

The geochemical data obtained are consistent with those of Aghajari Formation sandstones, deposited in an active and passive margin settings [6]. The optimum discrimination of sandstones representing the various tectonic settings is achieved by the plots of $\mathrm{Fe}_{2} \mathrm{O}_{3}+\mathrm{MgO}$ versus $\mathrm{TiO}_{2}, \mathrm{Al}_{2} \mathrm{O}_{3} / \mathrm{SiO}_{2}, \mathrm{~K}_{2} \mathrm{O} / \mathrm{Na}_{2} \mathrm{O}$, and $\mathrm{Al}_{2} \mathrm{O}_{3}$ / $\left(\mathrm{CaO}+\mathrm{Na}_{2} \mathrm{O}\right)$ (Fig. 6). Active continental margin sandstones are dominantly derived from the uplifted basement and reflect the composition of the upper continental crust [6]. Sediments of passive continental margins generally are considered to be mature $[41,42]$, and are deposited in plate interiors at stable continental margin or intra-cratonic basins. The Aghajari Formation sandstones are plotted in the field of the active and passive continental margin settings. 

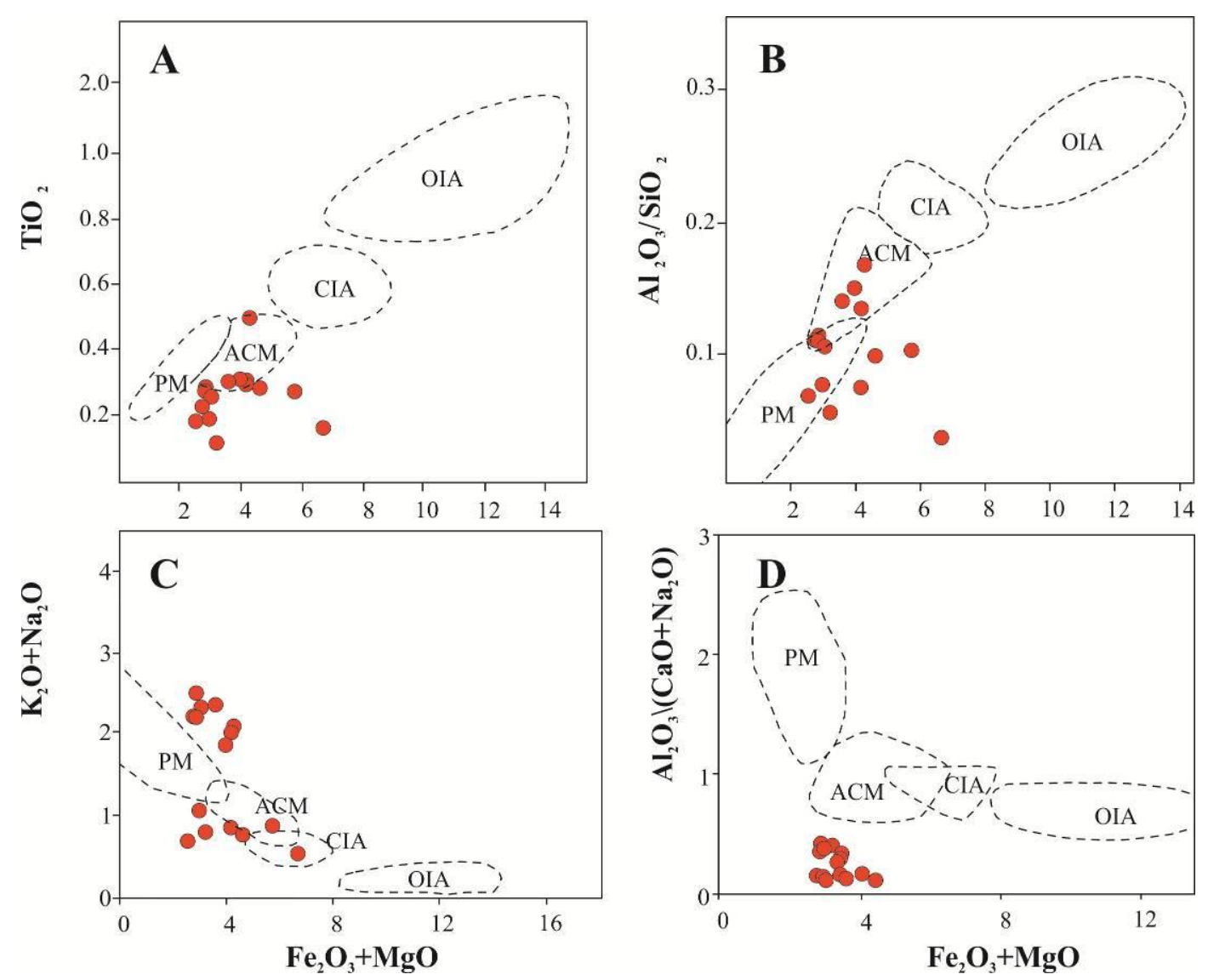

Fig. 6- Plots of the major element composition of the Aghajari Formation sandstones on the tectonic setting discrimination diagrams of Bhatia [6]. OIA: Oceanic island Arc, CIA: continental island Arc, ACM: active continental margin, PM: passive continental margin.

The $\mathrm{K}_{2} \mathrm{O} / \mathrm{Na}_{2} \mathrm{O}$ versus $\mathrm{SiO}_{2}$ diagram is widely used for discriminating between sediments deposited in the passive margin, active margin, and island arc settings [26]. The ratio of $\mathrm{K}_{2} \mathrm{O} / \mathrm{Na}_{2} \mathrm{O}$ variation with $\mathrm{SiO}_{2}$ is plotted in a binary diagram to understand the tectonic setting of the Aghajari Formation sediments (Fig. 7A). It is found from this plot that all samples are plotted in the active and passive continental margin fields. The same pattern is observed when the sandstone samples are plotted on the $\mathrm{SiO}_{2} / \mathrm{Al}_{2} \mathrm{O}_{3}$ versus $\mathrm{Na}_{2} \mathrm{O}+\mathrm{K}_{2} \mathrm{O}$ diagram (Fig. 7B). 

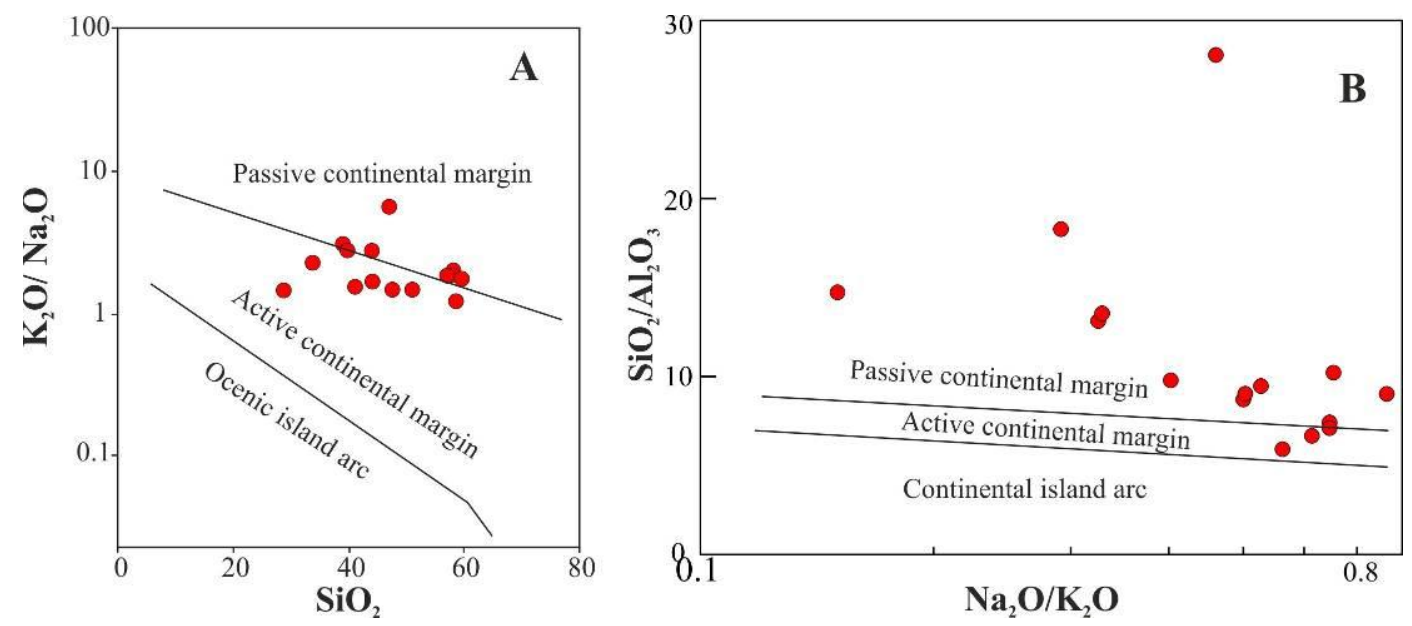

Fig. 7- Tectonic setting discrimination diagrams based on major element compositions of Aghajari Formation sandstone samples. A: $\mathrm{K}_{2} \mathrm{O} / \mathrm{Na}_{2} \mathrm{O}$ versus $\mathrm{SiO}_{2} ; \mathrm{B}: \mathrm{SiO}_{2} / \mathrm{Al}_{2} \mathrm{O}_{3}$ versus $\mathrm{K}_{2} \mathrm{O} / \mathrm{Na}_{2} \mathrm{O}$ (after [26]).

Also, plotting chemical contents of the studied sediments on the discrimination diagram of Bhatia [6] (Fig. 8) indicate that the samples fall within the active and passive margin fields.

Trace elements (e.g., Ti, Co, La, Th, Sc, and Zr) in the clastic sedimentary rocks are considered to be immobile under conditions of weathering, diagenesis, and moderate levels of metamorphism, and are commonly preserved in sedimentary rocks. Therefore, the trace elements represent well-established provenance and tectonic setting indicators [26, 34, 44]. On the Th-Sc-Zr/10 diagram (Fig. 9A), data related to the sandstone samples are plotted in the active continental margin setting; one of the data elements is plotted in continental island arc setting and one is plotted outside the settings. When plotted on the $\mathrm{La} / \mathrm{Sc}$ versus $\mathrm{Ti} / \mathrm{Zr}$ and $\mathrm{La} / \mathrm{Y}$ versus $\mathrm{Sc} / \mathrm{Cr}$ discrimination diagrams of Bhatia and Crook ${ }^{[26]}$ (Figs. 9B and C), most of sandstone samples cluster within the active continental margin and passive continental margin fields, respectively. 


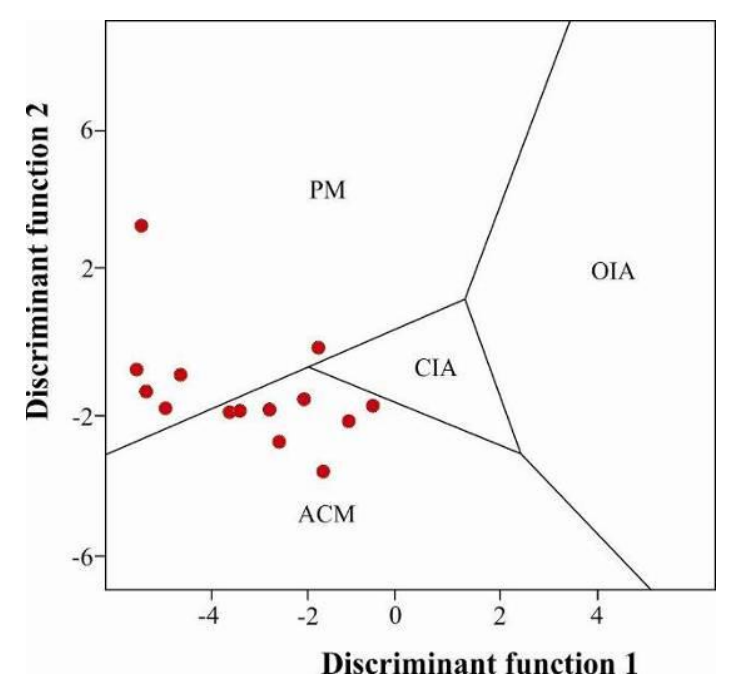

Fig. 8- Plots of the major element composition of the Aghajari Formation sandstones on the tectonic setting discrimination diagrams of Bhatia ${ }^{[6]}$. OIA: Oceanic island Arc; CIA: Continental island Arc; ACM: Active continental margin; PM: Passive continental margin.

\section{Source Area Weathering}

Chemical weathering affects, to a great extent, the composition of siliciclastic sediments. Through these processes the large cations (e.g. Ba, Al) remain preserved in the weathering residue in contrast to the smaller cations $(\mathrm{Na}, \mathrm{Ca}, \mathrm{Sr})$ that can be selectively removed $[30,45]$.
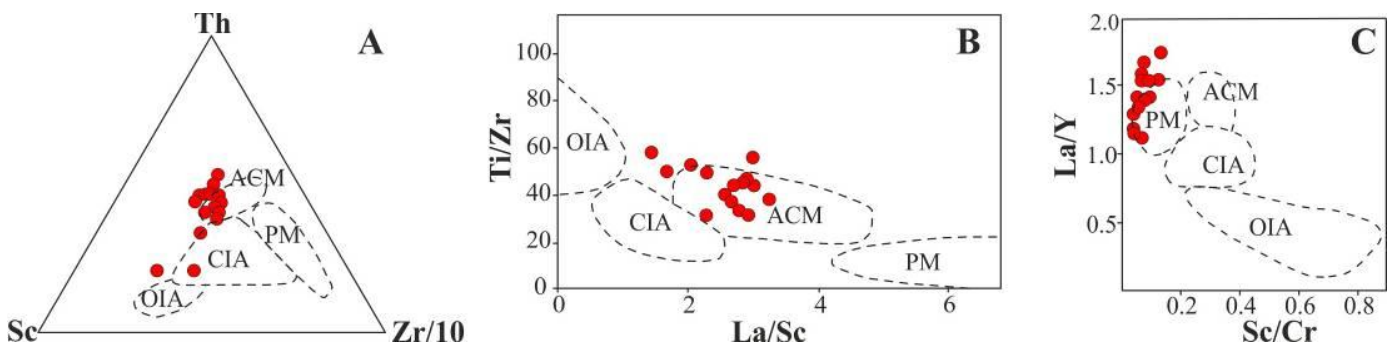

Fig. 9- Plots of the trace element composition of the Aghajari Formation sandstone samples on the tectonic setting discrimination diagrams of Bhatia and Crook [26]. OIA: Oceanic island Arc; CIA: Continental island Arc; ACM: Active continental margin; PM: Passive continental margin.

The degree of weathering may be assessed by the Chemical index of alteration $\left(\mathrm{CIA}=100 \times\left[\mathrm{Al}_{2} \mathrm{O}_{3} /\left(\mathrm{Al}_{2} \mathrm{O}_{3}+\mathrm{CaO}^{*}+\mathrm{Na}_{2} \mathrm{O}+\mathrm{K}_{2} \mathrm{O}\right)\right] ;{ }^{[23]}\right)$. All data in this formula is molecular proportions. $\mathrm{CaO}^{*}$ represents the value of $\mathrm{Ca}$ in the silicate fraction only. No carbonates were found in the samples examined. According to 
the methods of McLennan [46], we calculated and corrected $\mathrm{CaO}^{*} . \mathrm{CaO}$ corrected for apatite using $\mathrm{P}_{2} \mathrm{O}_{5}\left(\mathrm{CaO}^{*}=\mathrm{CaO}-\left(10 / 3 \times \mathrm{P}_{2} \mathrm{O}_{5}\right)\right)$. If the corrected $\mathrm{CaO}^{*}$ was less than the amount of $\mathrm{Na} 2 \mathrm{O}$, this corrected $\mathrm{CaO}^{*}$ value was adopted. In this regard, if the $\mathrm{CaO}^{*}$ value is greater than the amount of $\mathrm{Na}_{2} \mathrm{O}$, it was assumed that the concentration of $\mathrm{CaO}$ equals that of $\mathrm{Na}_{2} \mathrm{O}$.

The CIA values of approximately 50 imply an unweathered upper crust or weak weathering, whereas CIA values of 100 indicate intense weathering with a complete removal of alkali and alkaline earth elements and an increase in $\mathrm{Al}_{2} \mathrm{O}_{3}$ [46, 47, 48]. The calculated CIA values (Table 1) of sandstone samples range from 59.2 to 77.14 , with an average of 64.69. However, most samples have values greater than 60 , suggesting moderate to high weathering either of the original source or during transport before deposition. Its lower part show lower alteration values (CIA) than the upper part.

\section{Conclusion}

Element composition, inter-element ratios (e.g., $\mathrm{Na}_{2} \mathrm{O} / \mathrm{K}_{2} \mathrm{O}, \mathrm{Al}_{2} \mathrm{O}_{3} / \mathrm{TiO}_{2}, \mathrm{TiO}_{2} / \mathrm{Zr}$, $\mathrm{K} / \mathrm{Rb}, \mathrm{La} / \mathrm{Co}, \mathrm{Cr} / \mathrm{Ni}, \mathrm{Co} / \mathrm{Th}, \mathrm{La} / \mathrm{Sc}, \mathrm{Sc} / \mathrm{Th}, \mathrm{Cr} / \mathrm{Th}, \mathrm{Y} / \mathrm{Ni}, \mathrm{Cr} / \mathrm{Zr}$, and $\mathrm{Zr} / \mathrm{Sc}$ ), and source rock discrimination diagrams (e.g., $\mathrm{SiO}_{2}$ versus $\mathrm{K}_{2} \mathrm{O} / \mathrm{Na}_{2} \mathrm{O}, \mathrm{SiO}_{2} / \mathrm{Al}_{2} \mathrm{O}_{3}$ versus $\mathrm{K}_{2} \mathrm{O} / \mathrm{Na}_{2} \mathrm{O}, \mathrm{Al}_{2} \mathrm{O}_{3} / \mathrm{SiO}_{2}$ versus $\mathrm{Fe}_{2} \mathrm{O}_{3}+\mathrm{MgO}, \mathrm{Al}_{2} \mathrm{O}_{3} /\left(\mathrm{CaO}+\mathrm{Na}_{2} \mathrm{O}\right)$ versus $\mathrm{Fe}_{2} \mathrm{O}_{3}+\mathrm{MgO}, \mathrm{TiO}_{2}$ versus $\mathrm{Fe}_{2} \mathrm{O}_{3}+\mathrm{MgO}, \mathrm{K}_{2} \mathrm{O} / \mathrm{Na}_{2} \mathrm{O}$ versus $\mathrm{Fe}_{2} \mathrm{O}_{3}+\mathrm{MgO}$, Th-Sc$\mathrm{Zr} / 10$, Ti/Zr versus $\mathrm{La} / \mathrm{Sc}$, and $\mathrm{La} / \mathrm{Y}$ versus $\mathrm{Sc} / \mathrm{Cr}$ ), indicate that the Aghajari Formation sediments originated from felsic and intermediate, moderate weathering source rocks within the active and passive continental margin settings. The low/moderate CIA values as well as the low $\mathrm{Th} / \mathrm{Sc}$ ratio ${ }^{[4]}$ suggest that the source rocks for the Aghajari Formation sediments might be from a mixed old continental source, composed of granitic plutonic rocks. Sandstone samples with a high abundance of $\mathrm{Cr}$ and a high ratio of $\mathrm{Th} / \mathrm{Sc}$ were most likely to be derived from a mafic provenance. Moreover, the obtained data are consistent with a long distance transport, in a variable climate, over the Arabian shield, which supplied these sands to their depositional basin along the passive margin of the Late Miocene-Pliocene Zagros foreland basin.

\section{Acknowledgements}

We thank the Islamic Azad University, Khorasgan (Esfahan) Branch and Geological Survey of Iran for providing laboratory equipments. In addition, we are grateful to Dr S.H. Hejazi, A. Heydarieh, H. Heydari, M. Farajzadeh and J. Maniani for them considerable help throughout this study. 


\section{References}

[1] Yan, Y., Xia, B., Lin, G., et al., "Geochemistry of the sedimentary rocks from the Nanxiong Basin, South China and implications for provenance, paleoenvironment and paleoclimate at the K/T boundary", Sedimentary Geology, Vol. 197, (2007), pp. 127-140.

[2] Taylor, S.R., McLennan, S.M., The continental crust: Its composition and evolution, Blackwell Scientific, Oxford, (1985).

[3] Roser, B.P., Korsch, R.J., "Provenance signatures of sandstone- mudstone suites determined using discriminant function analysis of major-element data", Chemical Geology, Vol. 67, (1988), pp. 119- 139.

[4] Cullers, R.L., "The geochemistry of shales, siltstones and sandstones of Pennsylvanian-Permian age, Colorado, USA: Implications for provenance and metamorphic studies", Lithos, Vol. 51, (2000), pp. 181- 203.

[5] Qiugen, L., Shuwen, L., Baofu, H., et al., "Geochemical characteristics of the metapelites from the Xingxingxia group in the eastern segments of the Central Tianshan: Implications for the provenance and paleoweathering", Science in China Series D Earth Sciences, Vol. 48, (2005), pp. 1637- 1648.

[6] Bhatia, M.R., "Plate tectonics and geochemical composition of sandstones", Journal of Geology, Vol. 92, (1983), pp. 181- 193.

[7] Blatt, H., "Provenance studies and mudrocks", Journal of Sedimentary Petrology, Vol. 55, (1985), pp. 69- 75.

[8] Condie, K.C., "Chemical composition and evolution of upper continental crust: contrasting results from surface samples and shales", Chemical Geology, Vol. 104, (1993), pp. 1- 37.

[9] Hayashi, K., Fujisawa, H., Holland, H.D., et al., "Geochemistry of $1.9 \mathrm{Ga}$ sedimentary rocks from northeastern Labrador, Canada", Geochimica et Cosmochimica Acta, Vol. 61, (1997), pp. 4115- 4137.

[10] Kasanzu, C., Maboko, M.A.H., Manya, S., "Geochemisrty of fine grained clastic sedimentary rocks of the Neoproterozoic Ikorongo Group, NE Tanzania: Implication for provenance and source rock weathering", Precambrian Research, Vol. 164, (2008), pp. 201- 213.

[11] Paikaray, S., Banerjee, S., Mukherji, S., "Geochemistry of shales from Paleoprotozoic to Neoprotozoic Vindhyan Supergroup: Implicayions on provenance, tectonics and paleoweathering", Journal of Asian Earth Sciences, Vol. 32, (2008), pp. 34- 48.

[12] Stocklin, J., Possible ancient continental margins in Iran, In: Burk, C.A., Drake, C.L. (Eds), The Geology of Continental Margins. New York, Springer, 1974, pp. 873- 887.

[13] Berberian, M., King, G.C.P., "Towards the paleogeography and tectonic evolution of Iran", Canadian Journal of the Earth Sciences, Vol. 18, (1981), pp. 210- 265. 
[14] Beydoun, Z.R., Hughes Clarke, M.W., Stoneley, R., "Petroleum in the Zagros basin: A Late Tertiary foreland basin overprinted onto the outer edge of a vast hydrocarbon- rich Palaeozoic- Mesozoic passive margin shelf", AAPG Bulletin, Vol. 55, (1992), pp. 309- 339.

[15] Sahraeyan, M., Bahrami, M., " Petrography and provenance of sandstones from the Aghajari Formation, Folded Zagros Zone, southwestern Iran", International Journal of Basic and Applied Sciences, Vol. 1, No. 3, (2012), pp. 283- 298.

[16] James, G.A., Wynd, J.G., "Stratigraphic nomenclature of Iranian oil consortium agreement Area", AAPG Bulletin, Vol. 49, No. 12, (1965), pp. 2182- 2245.

[17] Motiei, H., Stratigraphy of Zagros, Tehran, Geological Survey of Iran, (1993).

[18] Stocklin, J., Stratigraphic Lexicon of Iran, Geological Survey Of Iran, Report No. 18, 1977.

[19] Al-Husseini, M.I., "Middle East Geological Timescale 2008", Journal of Middle East Petroleum and Geoscience, Vol. 13, No. 4, (2008).

[20] Bahrami, M., "Sedimentology and morphotectonical evolution of Aghajari and Bakhtiari Formations in north-western of Shiraz, Iran", Journal of Science, Islamic Azad University, Vol. 8, No. 27\&28, (1998), pp. 1995- 2010.

[21] Bahrami, M., "Lithofacies and Sedimentary Environments of Aghajari Formation in Dehsheikh Mountain, West of Shiraz, Iran", World Applied Science Journal, Vol. 6, No. 4, (2009), pp. 464- 473.

[22] Sahraeyan, M., Bahrami, M., Hejazi, S.H., "Facies and sedimentary environments of Aghajari Formation in southeast of Sarvestan, Folded Zagros Zone, Iran", Proceedings of the conference of application of earth sciences in fundamental researchs of Iran, (2011), pp. 168- 175.

[23] Nesbitt, H.W., Young, G.M., "Early Proterozoic climates and plate motions inferred from major element chemistry of lutites", Nature, Vol. 299, (1982), pp. $715-717$.

[24] Herron, M.M., "Geochemical classification of terrigeneous sands and shales from core or log data", Journal of Sedimentary Petrology, Vol. 58, (1988), pp. 820- 829.

[25] Pettijohn, F.J., Potter, P.E., Siever, R., Sand and Sandstone, second ed., Springer, New York, (1987).

[26] Roser, B.P., Korsch, R.J., "Determination of tectonic setting of sandstone mudstone suites using $\mathrm{SiO}_{2}$ content and $\mathrm{K}_{2} \mathrm{O} / \mathrm{Na}_{2} \mathrm{O}$ ratio", Journal of Geology, Vol. 94, (1986), pp. 635- 650.

[27] Nesbitt, H.W., Markovics, G., Price, R.C., "Chemical processes affecting alkalis and alkaline earths during continental weathering", Geochimica et Cosmochimica Acta, Vol. 44, (1980), pp. 1659- 1666.

[28] Wronkiewicz, D.J., Condie, K.C., "Geochemistry of Archean shales from the Witwatersland Supergroup, South Africa: source area weathering and provenance", Geochimica et Cosmochimica Acta, Vol. 51, (1987), pp. 24012416. 
[29] McLennan, S.M., Taylor, S.R., Eriksson, K.A., "Geochemistry of Archaean shales from the Pilbara Supergroup, Western Australia", Geochimica et Cosmochimica Acta, Vol. 47, No. 7, (1983), pp. 1211- 1222.

[30] Nath, B.N., Kunzendorf, H., Pluger, W.L., "Influence of provenance, weathering and sedimentary processes on the elemental ratio of the finegrained fraction of the bed load sediments from the Vembanad Lake and the adjoining continental shelf, southwest Coast of India", Journal of Sedimentary Research, Vol. 70, (2000), pp. 1081- 1094.

[31] Zhang, K.L., "Secular geochemical variations of the Lower Cretaceous siliciclastic from central Tibet (China) indicate a tectonic transition from continental collision to back-arc rifting", Earth and Planetary Science Letters, Vol. 229, (2004), pp. 73- 89.

[32] Osae, S., Asiedu, D.K., Yakubo, B., et al., "Provenance and tectonic setting of Late Proterozoic Buem sandstones of southeastern Ghana: Evidence from geochemistry and detrital modes", Journal of African Earth Science, Vol. 44, (2006), pp. 85- 96.

[33] Huntsman-Mapila, P., Kampunzu, A.B., Vink, B., et al., "Cryptic indicators of provenance from the geochemistry of the Okavango Delta sediments, Bostwana", Sedimentary Geology, Vol. 174, (2005), pp. 123- 148.

[34] Spalletti, L.A., Queralt, I., Matheos, S.D., et al., "Sedimentary petrology and geochemistry of siliciclastic rocks from the upper Jurassic Tordillo Formation (Neuquen Basin, western Argentina): Implications for provenance and tectonic setting", Journal of South American Earth Sciences, Vol. 25, (2008), pp. 440- 463.

[35] McLennan, S.M., Nance, W.B., Taylor, S.R., "Rare earth element-thorium correlations in sedimentary rocks and the composition of the continental crust", Geochimica et Cosmochimica Acta, Vol. 44, (1980), pp. 1833- 1839.

[36] Cullers, R.L., "Implications of elemental concentrations for provenance, redox conditions, and metamorphic studies of shales and limestones near Pueblo, CO, USA", Chemical Geolology, Vol. 191, No. 4, (2002), pp. 305327.

[37] Nagarajan, R., Armstrong-Altrin, J.S., Nagendra, R., et al., "Petrography and geochemistry of terrigenous sedimentary rocks in the Neoproterozoic Rabanpalli Formation, Bhima Basin, southern India: Implications for paleoweathering condition, provenance, and source rock composition", Journal of Geology Society of India, Vol. 70, No. 2, (2007a), pp. 297- 312.

[38] Nagarajan, R., Madhavaraju, J., Nagendra, R., et al., "Geochemistry of Neoproterozoic shales of Rabanpalli Formation, Bhima Basin, Northern Karnataka, Southern India: Implications for provenance and paleoredox conditions", Revista Mexicana Ciencias Geologicas, Vol. 24, No. 2, (2007b), pp. 150- 160.

[39] McLennan, S.M., Taylor, S.R., "Sedimentary rocks and crustal evolution: tectonic setting and secular trends", Journal of Geology, Vol. 99, (1991), pp. 1- 21. 
[40] Armstrong-Altrin, J.S., Lee, Y., Verma, S., et al., "Geochemistry of sandstones from the Upper Miocene Kudanul Formation, southern India: Implications for provenance, weathering tectonic setting", Journal of Sedimentary Research, Vol. 74, (2004), pp. 167- 179.

[41] Crook, K.A.W., Lithogenesis and tectonics: the significance of compositional variation in flysch arenites (greywackes), In: Dott, R.H., Shaver, R.H. (Eds), Modern and Ancient Geosynclinal Sedimentation, Special Publication 19, Society of Economic Geologists and Paleontologists, 1974, 304- 310.

[42] Schwab, F.L., "Framework mineralogy and chemical composition of continental margin-type sandstone", Geology, Vol. 3, (1975), pp. 487- 490.

[43] Bhatia, M.R., Crook, K.A.W., "Trace element characteristics of graywackes and tectonic setting discrimination of sedimentary basins", Contributions to Mineralogy and Petrology,Vol. 92, (1986), pp. 181- 193.

[44] McLennan, S.M., Hemming. S., McDaniel. D.K., et al., Geochemical approaches to sedimentation, provenance, and tectonics. In: Johnsson, M.J., Basu, A. (Eds), Processes controlling the composition of clastic sediments, Geology Society of American Special Paper, Vol. 284, (1993), pp. 21- 40.

[45] Fedo, C.M., Eriksson, K., Krogstad, E.J., "Geochemistry of shales from the Archean (3.0 Ga.) Buhwa Greenstone Belt, Zimbabwe: Implications for provenance and source area weathering", Geochimica et Cosmochimica Acta, Vol. 60, (1996), pp. 1751- 1763.

[46] McLennan, S.M., "Weathering and global denudation", Journal of Geology, Vol. 101, (1993), pp. 295- 303.

[47] Fedo, C.M., Nesbitt, H.W., Young, G.M., "Unraveling the effects of potassium metasomatism in sedimentary rock sand paleosols, with implications for paleoweathering conditions and provenance", Geology, Vol. 23, (1995), pp. 921- 924.

[48] Dupuis, C., Hebert, R., Cote, V.D., et al., "Geochemistry of sedimentary rocks melange and flysch units south of the Yarlung Zangbo suture zone, southern Tibet", Journal of Asian Earth Sciences, Vol. 26, (2006), pp. 489508 . 